\title{
СОВРЕМЕННОЕ СОСТОЯНИЕ И ПЕРСПЕКТИВЫ РАЗВИТИЯ СТРАХОВАНИЯ ЖИЗНИ В РОССИИ
}

\author{
(C) 2020 Жегалова Елена Валерьевна \\ кандидат экономических наук, доцент кафедры финансов и кредита \\ Самарский государственный экономический университет, Россия, Самара \\ E-mail: zhegalova@rambler.ru
}

В статье рассматриваются современное состояние отечественного страхового рынка, а также его основного драйвера роста - страхования жизни, выделяются проблемы и определяются направления совершенствования страхования жизни в России.

Ключевые слова: страховой рынок, страхование жизни, инвестиционный потенциал страхования жизни, продукты накопительного и инвестиционного страхования жизни, налоговый вычет.

В настоящее время уровень российского страхового рынка не соответствует потребностям реального сектора экономики и не стимулирует социальное развитие общества. В 2019 г. российский страховой рынок впервые с 2009 г. перестал расти: объем собранных премий практически не изменился (1,48 трлн. руб., + 0,4\% к 2018 г., прирост в 2018 г. $+15 \%$ к 2017 г.), а объем выплат значительно вырос (до 609,6 млрд. руб., + 16,7\% к 2018 г.). Основная причина, как отмечает регулятор Банк России - снижение сегмента инвестиционного страхования жизни (ИСЖ) до 317 млрд. руб. (-19,2\% к 2018 г.) вследствие повышения стандартов продаж и невысокой инвестиционной доходности - от $1,9 \%$ до $2,4 \%$ годовой доходности в зависимости от срока договора. Банк России выделил кредитное страхование физических лиц в качестве одного из возможных драйверов развития рынка в 2020-2021 годах, поскольку в 2019 г. наблюдался рост страхования жизни и здоровья заёмщиков.

Сочетание нисходящей динамики неттопремий и увеличения сумм выплат по страховым договорам свидетельствуют о нарастающем снижении рентабельности бизнеса. Сложившаяся экономическая ситуация в стране не дает страховщикам возможностей для роста и развития страховых продуктов и развития новых сегментов в сфере страхования. Регулятивные требования об увеличении сумм уставного капитала, появление большого количества конкурентов на рынке, превышение темпов роста страховых выплат страхователям над темпами роста страховых премий также не дают возможности небольшим страховым организациям сохранять положительную динамику своих эконо- мических показателей. Именно такие условия провоцируют дальнейшее сокращение страховых организаций на рынке страховых услуг. Так, по состоянию на 01.10.2020 г. в реестре субъектов страхового дела числилось 165 страховщиков, и это уже на 21 компанию меньше, чем в 2019 г. Из этого количества страховых организаций 100 страховщиков являются универсальными страховыми компаниями, 30 - занимаются страхованием жизни, 31 - специализируются на обязательном медицинском страховании и $4-$ являются перестраховочными организациями.

Рынок страхования стремительно сокращается, что вызвано жесткой политикой Банка России по отношению к недобросовестным участникам рынка. Именно поэтому, деятельность Центрального Банка вызывает двойственное отношение на рынке, так как, с одной стороны, регулятор действует в целях реализации главной задачи страхования- обеспечение защиты страхователей и оставляет на финансовом рынке только надежные страховые компании для заключения договоров. С другой стороны, убирая с рынка многих участников, Центральный Банк создает условия монополизированного страхового рынка, что противоречит главной цели экономики любого государства.

В России современный страховой рынок продолжает функционировать в сложных экономических условиях финансового кризиса, и в то же время, страхование жизни демонстрирует стабильный рост сборов страховой премий и является самым динамичным и быстрорастущим сегментом страхового рынка, хотя его доля снизилась в 2019 году с $31 \%$ до $28 \%$.

Страхование жизни является одним из клю- 
чевых механизмов защиты имущественных интересов и финансового планирования у населения во всем мире.

За 2019 год страховщики жизни собрали более 433 млрд. руб. Это всего на 9\% меньше, чем в 2018 году, и на 20\% больше, чем в 2017 году. При этом 300 из 433 млрд. руб., или 70\% всех взносов, составили сборы по долгосрочным инвестиционно-накопительным программам страхования жизни. Отметим, что еще в 1-м квартале 2019 года темпы падения роста взносов по сравнению с 2018 г. превышали 30\%. Это было вызвано ужесточением регулирования, низкой доходностью по ИСЖ, вследствие неэффективной работы фондовых рынков в 2018 году, активизацией конкурентов на других рынках, предлагающих схожие с ИСЖ продукты.

Падение рынка имело и положительный эффект для страховщиков жизни, так как на рынке появились новые интересные продукты, объединяющие преимущества инвестиционного страхования и структурных нот, целый спектр валютных продуктов.

Накопительное страхование, ставшее самым быстрорастущим сегментом рынка страхования жизни, начало развиваться в сторону повышения качества самих продуктов за счет расширения сервисных составляющих, таких, как медицинские и консьерж сервисы, финансовые сервисы, оформление налогового вычета или консультирование по составлению портфеля финансовых инструментов. Появилось инвестиционное страхование жизни с регулярными взносами, представляющее собой накопительное страхование с возможностью выбора инвестиционной стратегии.

Средства страховщиков жизни во всем мире представляют собой значительные стратегические резервы, они аккумулируются в крупные финансовые потоки, инвестируются в различные крупные государственные национальные проекты, и для любого государства представляют значительный инвестиционный потенциал.

В России по данным мегарегулятора, по состоянию на 31 декабря 2019 года объем резервов страховщиков жизни составил почти 1,2 трлн. рублей. Доля государственных облигаций в активах страховщиков составляет 19,1\%, корпоративных облигаций $-25,2 \%$.

Таким образом, вложения страховщиков жизни в государственные бумаги сопоставимы со стоимостью крупнейших инфраструктурных проектов страны, а сотни миллиардов рублей, которые страховщики жизни направляют на выкуп корпоративных облигаций,- это действительно, существенная поддержка российского корпоративного бизнеса.

На современном этапе российский рынок страхования жизни, прежде демонстрировавший динамичные быстрые темпы, начал замедляться после того, как начали работать меры по борьбе с мисселингом.

В «Стратегии развития страховой отрасли в Российской Федерации на 2019-2021 годы», разработанной ведущими страховщиками и профессионалами страхового дела, а так же Всероссийским союзом страховщиков было отмечено, что для российского страхового рынка характерен недостаточный уровень взаимного доверия, неразвитость инфраструктуры, наличие недобросовестных практик продаж. В 2019 г. вступил в силу стандарт по страхованию жизни, разработанный Всероссийским союзом страховщиков. Он предусматривал конкретные способы и формы информирования граждан о важных условиях договоров страхования жизни: выкупных суммах, инвестиционных рисках, периоде охлаждения и так далее.

С апреля 2019 г. введен еще и стандарт, разработанный Банком России, предусматривающий аттестацию страховых агентов, в том числе работников банков-агентов и сотрудников страховщика. Появилась ответственность страховых агентов и работников страховщика за невыполнение аттестационных требований.

При этом необходимо отметить, что стандарт Банка России гораздо более жесткий, чем стандарт от ВСС. Регулятор обязал страховщиков жизни письменно раскрывать перед клиентами все данные о продукте долгосрочного страхования жизни до подписания с ними договоров. Это касается, в первую очередь, информации об активах, в которые будут вложены денежные средства клиентов, порядке расчета и выплаты инвестиционного и гарантированного дохода, о совокупных взносах по программе и сумме инвестиций, порядке определения страховой суммы по каждому риску, выкупных суммах при досрочном расторжении. Указание ЦБ РФ также подразумевает раскрытие агентских и комиссионных вознаграждений страховщика и продавцов.

Оба нормативных документа существенно ужесточили правила продажи продуктов страхования жизни. 
Все это способствует повышению финансовой грамотности и доверия клиентов к страховым компаниям и банкам, продуктам накопительного и инвестиционного страхования жизни, поэтому жесткие стандарты продаж страховых продуктов полезны не только клиентам, но и самому страховому рынку.

Рынок страхования жизни в РФ все еще остается высоко концентрированным, хотя доля рынка, приходящаяся на его лидера по сравнению с первым полугодием 2020 года сократилась в 1,6 раза. На топ-5 страховщиков в 1 квартале 2020 года году пришлось $72,2 \%$ всей страховой премии, на лидера рынка - СК “Сбербанк страхование жизни” - 24\% всех сборов (годом ранее на топ-5 страховщиков приходилось 68,8\% всех сборов, а на СК “Сбербанк страхование жизни” - 39,1\%).

На рынке накопительного страхования жизни на топ-5 страховщиков пришлось 78,3\% премий, на лидера рынка - 33,6\%. На рынке ИСЖ топ-5 страховщиков собрали $76,2 \%$ премий, а на лидера рынка пришлось $25,2 \%$. Отметим, что страховая компания лидер "Сбербанк страхование жизни” еще в прошлом году изменила свою концепцию формирования страхового портфеля и переориентировалась с программ инвестиционного страхования жизни - на программы накопительного страхования.

После снятия законодательных ограничений на продажу страховых продуктов на онлайнплощадках Сбербанк первым из российских банков представил для страхователей полисы страхования жизни в собственном мобильном приложении. Теперь в приложении Сбербанк Онлайн всем клиентам стал доступен полный ассортимент инвестиционно-накопительных продуктов, включая страхование жизни, паевые инвестиционные фонды, индивидуальный инвестиционный счет (ИИС) с доверительным управлением, индивидуальные пенсионные планы (ИПП).

Снятие ограничений на страхование жизни онлайн становится значимым стимулом для дальнейшего развития и цифрового страхования, и классического страхования жизни.

В 2020 году ведущим направлением на страховом рынке по-прежнему продолжает оставаться накопительное страхование жизни (НСЖ) - рост по этому виду в 1 полугодии 2020 года по сравнению с аналогичным прошлогодним периодом составил $26 \%$ - премии выросли с 44,7 до 56,2 млрд. рублей. Предыдущий сектор - инвестиционное страхование жизни (ИСЖ) - показал снижение сборов на $11 \%$ - с 92,3 до 82,2 млрд. рублей.

Одна из причин сокращения рынка ИСЖ получаемая страховщиками фактическая доходность: она намного ниже заявленной при продаже в банках. Несмотря на незначительный рост доходности полисов ИСЖ, закончивших свое действие в I квартале 2020 г., в среднем она по-прежнему уступает ставкам по депозитам (по вкладам в топ-10 банков, по данным ЦБ РФ, примерно 4,5\%).

Так, 66\% полисов ИСЖ, завершившихся в период с 2018 г. по I квартал 2020 г., показали доходность ниже 3\%, а $89 \%$ полисов - ниже $5 \%$. По данным ЦБ РФ 19\% всех полисов показали вообще нулевую доходность - то есть, результат инвестирования в этих случаях был либо нулевым, либо отрицательным, так как в соответствии с условиями договора данного инвестиционного продукта возврат суммы вложений страховщиком клиенту гарантирован.

В то же время, низкий уровень средней доходности ИСЖ вовсе не означает, что на рынке нет стратегий, приносящих доход существенно выше банковских депозитов. В конце 2019 г. компания «АльфаСтрахование-жизнь» запустила купонные продукты с условной защитой капитала для квалифицированных инвесторов со взносами в рублях, долларах США и евро; по стратегии «Зона комфорта» доходность в рублях составила 7,5\% годовых., а в июне 2020 г. клиенты, оформившие программу «Программный код», получили доходность из расчета 36\% годовых в рублях.

У страховой компании «Росгосстрах жизнь» инвестирование в акции Inditex по итогам 2019 г. принесло более $40 \%$, в акции Apple - $86 \%$ годовых в рублях.

Сегодня средняя сумма инвестиций по таким договорам страхования жизни составляет около 1 млн. рублей.

Таким образом, инвестиционные продукты страхования жизни на российском рынке пользуются заслуженным вниманием инвесторов и имеют потенциал роста. Аналитиками рынка прогнозируется рост сборов по страхованию жизни в 2020 году примерно на 6\% до ориентировочно 460 млрд. рублей.

Исследования, проводившееся специалистами страхового дела, экспертами и социологами, показали, что россияне готовы пользоваться 
разными продуктами по страхованию жизни, при условии, что сохранность их вложений в эти продукты будет гарантирована государством.

Таким образом, повышению интереса и доверия россиян к страхованию жизни будет, в частности, способствовать распространение на страхование жизни системы государственного гарантирования возврата инвестированных средств по аналогии с банковскими вкладами, которое, как ожидается появится в России уже в 2021 году.

В целях дальнейшего развития рынка корпоративного личного страхования жизни и здоровья сотрудников компаний необходимо законодательное введение налоговых льгот для работодателей, как это успешно и давно применяется на страховых рынках в других странах.

В настоящее время специалистами страхового рынка совместно с Всероссийским союзом страховщиков были предложены меры по развитию и совершенствованию страхования жизни в РФ. Так, при обсуждения готовящейся правительственной концепции развития страхового рынка на период до 2024 года Всероссийский союз страховщиков предложил снизить срок длительности договоров страхования жизни, в отношении которых возможно применять социальный налоговый вычет, с пяти до трех лет.

Это повысит привлекательность и доступность страховой защиты для физических лиц, так как в современных условиях кризиса и «зыбкости» финансового планирования решение о снижении сроков договоров и оптимизации налогового вычета позволило бы расширить круг заинтересованных клиентов страховщикам жизни.

В кризис потребители отдают обычно предпочтение договорам страхования с небольшим сроком накоплений. Сейчас к финансовому планированию, предполагающему 5-летние на- копления, инвесторы стали относиться с большей осторожностью, программы долгосрочного страхования жизни при резком изменении конъюнктуры финансового рынка не позволяют легко выйти из инвестиций, досрочный выход из таких программ влечет для клиентов страховых компаний денежные потери.

В целях повышения финансовой грамотности клиентов при приобретении ими инвестиционных продуктов страхования жизни регулятором предлагается внести в законодательную базу дополнительные обязательства для банков по информированию потребителей при открытии банковского вклада и о правилах продаж финансовых инструментов, в том случае, когда банк выступает агентом страховой компании или иного участника рынка.

В целях совершенствования правил продаж инвестиционных продуктов и инструментов, обеспечения прозрачности и осведомленности потребителей финансовых услуг Банк России предложил ввести для продавцов финансовых услуг и их посредников обязанность представлять клиентам важную информацию о финансовом продукте в едином формате до момента его покупки - обязательный паспорт финансового продукта (или ключевой информационный документ),- не более 2-3 страниц разъясняющего текста. Паспортизация планирует охватить различные структурные продукты инвестиционного страхования жизни, внебиржевые производные финансовые инструменты, а также субординированные облигации, и повысить финансовую грамотность клиентов институтов финансового рынка.

Решение существующих проблем позволит обеспечить доверие инвесторов как к институту страхования жизни, так и способствовать дальнейшему развитию всего отечественного страхового рынка.

\section{Библиографический список}

1. «Ассоциация Страховщиков Жизни» http://aszh.ruhttp: //www.mskagency.ru/ [Электронный ресурс]. (дата обращения: 21. 10.2020).

2. Интернет-портал «Страхование сегодня» www.insur-info.ru [Электронный ресурс]. (дата обращения: 20.10.2020).

3. Интернет-портал «Страхование сегодня» https://www.insur-info.ru/life-insurance/press/160206/

4. Сайт Центрального банка Российской Федерации http://www.cbr.ru/sbrfr/ [Электронный ресурс]. (дата обращения: 21.10.2020).

5. Сайт Всероссийского союза страховщиков http://old.ins-union.ru/ [Электронный ресурс]. (дата обращения: 21.10.2020).

6. Стратегия развития страховой отрасли в Российской Федерации на 2019-2021 годы, утв. Общим собранием членов Всероссийского союза страховщиков, протокол № 21 от 2.11. 2018 